\title{
Some biological aspects of the portunid crab Charybdis natator from the Gulf of Suez, Red sea
}

\author{
Wafaa S. Sallam ${ }^{1}$ and Ali A. Gab-Alla ${ }^{2}$ \\ 1- Department of Marine Science, Suez Canal University, Ismailia, 41522, \\ Egypt. \\ 2- Biology Department, Faculty of Science, Um Al Qura University, \\ Makkah Al Mukarramah, Kingdom of Saudi Arabia. \\ Email: address: wafaasallam@yahoo.com, \\ Email: aligaballa2000@yahoo.com
}

\begin{abstract}
$\mathrm{T}$ he population of the portunid crab Charybdis natator in the Gulf of Suez, Red Sea was studied by monthly sampling from September 2007 to May 2008. Crabs were sexed, measured and berried females recorded. A total of 498 individuals were obtained, of which $232(46.6 \%)$ were males, 212 non-ovigerous females $(42.5 \%)$, and $54(10.9 \%)$ ovigerous females. The overall sex ratio (M:F) was (1:1.1) and females outnumbered females during September-November. The population showed sex differences in the size frequency distributions, with males reaching larger size than females $(70-148.4 \mathrm{~mm}$ and $47.5-130.5 \mathrm{~mm} \mathrm{CW}$, respectively). Ovigerous females existed all year round and ranged in size between $83-118.4 \mathrm{~mm} \mathrm{CW}$. Fecundity ranged from 45230 to 335529 eggs per female and was positively correlated with body size. The effectiveness of the closed season that runs in the Gulf of Suez on the population of C. natator was discussed.
\end{abstract}

Keywords: Charybdis natator, portunid crab, Red Sea.

\section{INTRODUCTION}

The portunid crab Charybdis natator (Herbst, 1789) is a widespread Indo- West Pacific species. It is distributed along East Africa, Madagascar, Red Sea, India, China, Japan, Philippines, Thailand, Malaysia, Singapore, Indonesia and Australia (Stephenson et al., 1958; Dai et al., 1986; Dai \& Yang, 1991). Although not supporting a large fishery in any area of its range, it contributes to crab fisheries in India (Menon, 1952), Australia (Sumpton, 1990a) and Taiwan (Lui et al., 2007). In these areas the more common blue crab, Portunus pelagicus (Linneaus, 1758) and mud crab, Scylla serrata (Forskåll, 1775) are more commercially important (Sumpton, 1990a). In the Egyptian waters of the Mediterranean, the biology of $P$. pelagicus has been extensively studied (AlKholy and El-Hawary, 1970; Abdel- Razek, 1988; Bawab and El-Sherif, 1988) as well as in the Red Sea (Zaghloul, 2003) and other parts of the world (Batoy et al., 1987, 1988, Kangas, 2000, Wang et al., 2001). Similarly, the biology of 
Scylla serrata has also been well documented (Hill, 1980; Hill et al., 1982, Hyland et al., 1984; Heasman et al., 1985).

On the other hand, little is known on the biology and life history of $C$. natator. Sumpton (1990 a, b) studied the reproductive biology and fisheries of this species in Moreton Bay, Australia while Islam et al. (2000) described the development of larvae reared in the laboratory. In the northern coasts of the Red Sea, this crab exists in the catches of trawlers operating in the Gulf of Suez and supports a small fishery. The fished quantities are introduced to the markets of Suez city together with the commercial species $P$. pelagicus but receive little attention from consumers (Sallam and Gab-Alla, 2009). Despite the closed season that runs from June to August in the Gulf of Suez region, samples of Charybdis natator were obtained during the remaining months of the year. This enabled the documentation of features of this species' population in the gulf including sex ratios, spawning season, biometric relationships and fecundity of the females. This paper presents these data and compares the biology of $C$. natator with other portunids.

\section{MATERIALS AND METHODS \\ Samples collection and processing:}

Trawlers depart El-Ataka Port at Suez heading towards the Gulf of Suez. Three fishing trips are made monthly, each lasting between 4-10 days. Fishing operations commence in the area opposite to Ras Ghareb Port. Trawling takes place at a depth ranging between 110-130 m. From September 2007 to May 2008, monthly visits were paid to the landing site at El-Ataka Port. Samples of Charybdis natator were obtained from the catches of the trawling vessels. Crabs were sexed, weighed on an electric balance $( \pm \mathrm{lg})$ and their carapace width $(\mathrm{CW})$ and length $(\mathrm{CL})$ were measured to the nearest millimeter using a vernier caliper. The stage of ovarian maturation of females was examined and noted according to the colour of the ovaries (Chu, 1999). Four stages were recognized: stage I (immature), colourless; stage II (maturing), white to ivory; stage III (mature), yellow to yellowish orange; and stage IV (ripe), orange. Incidence of gravid females was also recorded. For the estimation of fecundity, a sub-sample of the incubated eggs was taken from ovigerous females, weighed and the number of eggs counted. The remaining eggs were removed from the pleopods and subsequently weighed on a sensitive balance $( \pm 0.001 \mathrm{~g})$ and the number of eggs calculated. Statistical analysis followed Zar (1984).

\section{Population structure:}

\section{RESULTS}

A total of 496 individuals of $C$. natator were obtained, of which 232 (46.8\%) were males, 212 non-ovigerous females (42.7\%), and $52(10.5 \%)$ ovigerous females. Carapace width distributions of both sexes are shown in 
Figure 1. The population shows sex differences in the size frequency distributions, with males reaching larger size than females $(70-148.4 \mathrm{~mm}$ and $47.5-130.5 \mathrm{~mm} \mathrm{CW}$, respectively). Males were on average $(106.3 \mathrm{~mm} \mathrm{CW}$, $\mathrm{n}=232, \mathrm{SD}=19.6)$ larger than non-ovigerous females $(99.3 \mathrm{~mm} \mathrm{CW} \mathrm{n}=212$, $\mathrm{SD}=13.5)$ and ovigerous females $(101.9 \mathrm{~mm} \mathrm{CW} \mathrm{n}=54, \mathrm{SD}=10.9)$. All demographic categories were present except recruits. Small size groups (45-55, 55-65 mm CW) were predominantly constituted by females. A few number of females exceeded $130 \mathrm{~mm}$, whereas several males were larger than this size. The range size class was $95-205 \mathrm{~mm}$ for males and $105-115 \mathrm{~mm}$ for females. The overall sex ratio (Male: female) was (1:1.1) (fig. 2). Females outnumbered males throughout most of the year but there was a predominance of males during September-November. The ratio was insignificantly different from the expected $1: 1\left(X^{2}=2.06, P<0.01\right)$.

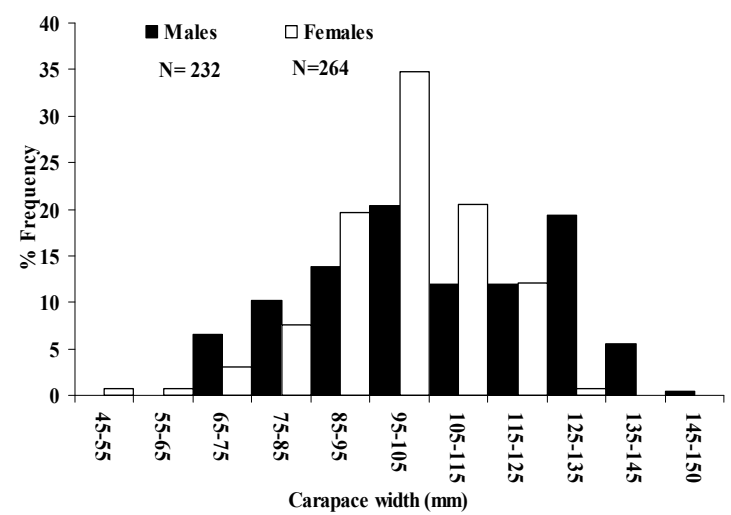

Fig. 1: Length frequency distribution of males and females Charybdis natator. $\mathrm{N}=$ number of individuals.

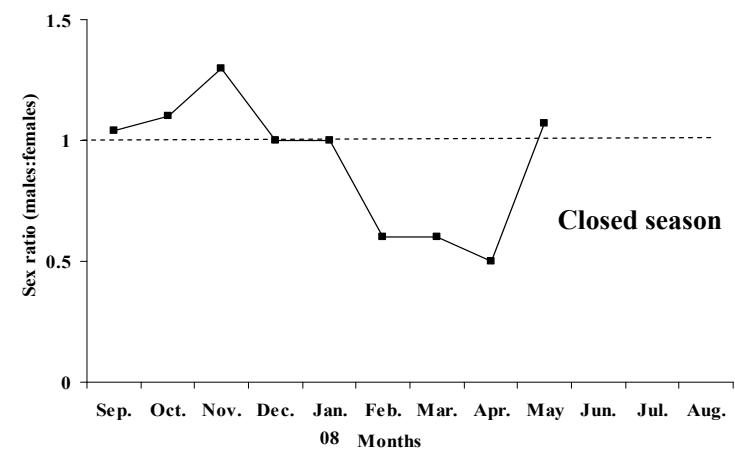

Fig. 2: Monthly variations in the sex ratio of Charybdis natator in the Gulf of Suez. Dotted line indicates ratio of 1:1 (males: females). 


\section{Biometric relationships:}

The relationships between wet weight (WWT) and carapace width (CW) for males and females are given in figure 3. The regression equations obtained for these relationships were: $\ln \mathrm{WWT}=2.9771 \ln \mathrm{CW}-8.2976\left(\mathrm{r}^{2}=0.89, P\right.$ $<0.05)$ for males and $\ln \mathrm{WWT}=3.064 \ln \mathrm{CW}-8.9071\left(\mathrm{r}^{2}=0.79, \mathrm{P}<0.05\right)$ for females. Analysis of covariance indicated significant differences in the equations of the two sexes $(\mathrm{t}=7.187, \mathrm{P}<0.05)$. Figure 4 displays the relationships between carapace width and carapace length (CL) for males and females. The regression equations obtained for these relationships were: $\mathrm{CL}=0.6607 \mathrm{CW}+1.3356\left(\mathrm{r}^{2}=\right.$ $0.97, \mathrm{P}<0.05)$ for males and: $\mathrm{CL}=0.6451 \mathrm{CW}+3.175\left(\mathrm{r}^{2}=0.98, P<0.05\right)$ for females. The analysis of covariance revealed that regression slopes differed significantly between the two sexes $(t=5.158, P<0.05)$.

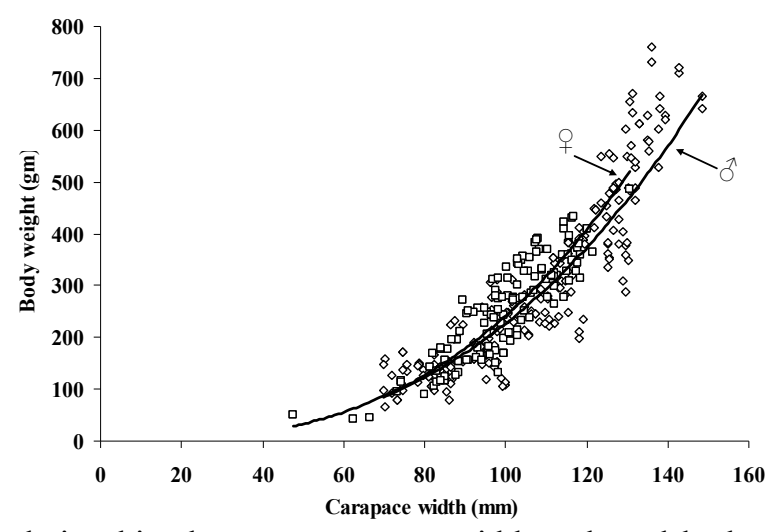

Fig. 3: Relationships between carapace width and total body weight for males and females Charybdis natator.

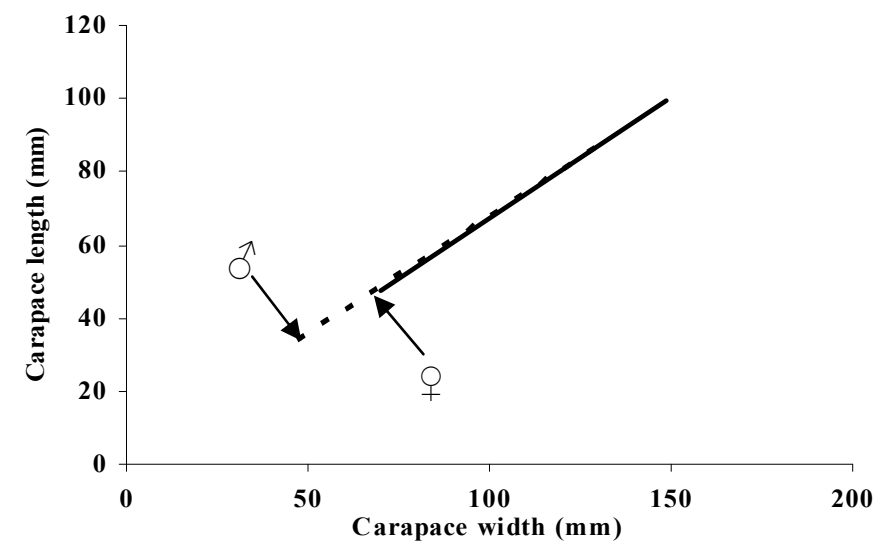

Fig. 4: Relationships between carapace width and length in males and females Charybdis natator. Dashed line for solid line for females 


\section{Seasonality of spawning:}

Monthly variations of the different maturation stages of female $C$. natator are given in figure 5. A period of gonadal activity for females lasting from November 2007 to March 2008 was apparent during which maturing and mature females existed with high percentages. This was followed by a resting phase that apparently passes through the period of the closed season (April and May) where females with undeveloped immature ovaries had their highest percentages. Ovigerous females that had developing or mature ovaries were observed in almost all months but their percentage declined between November and February (Fig.6).

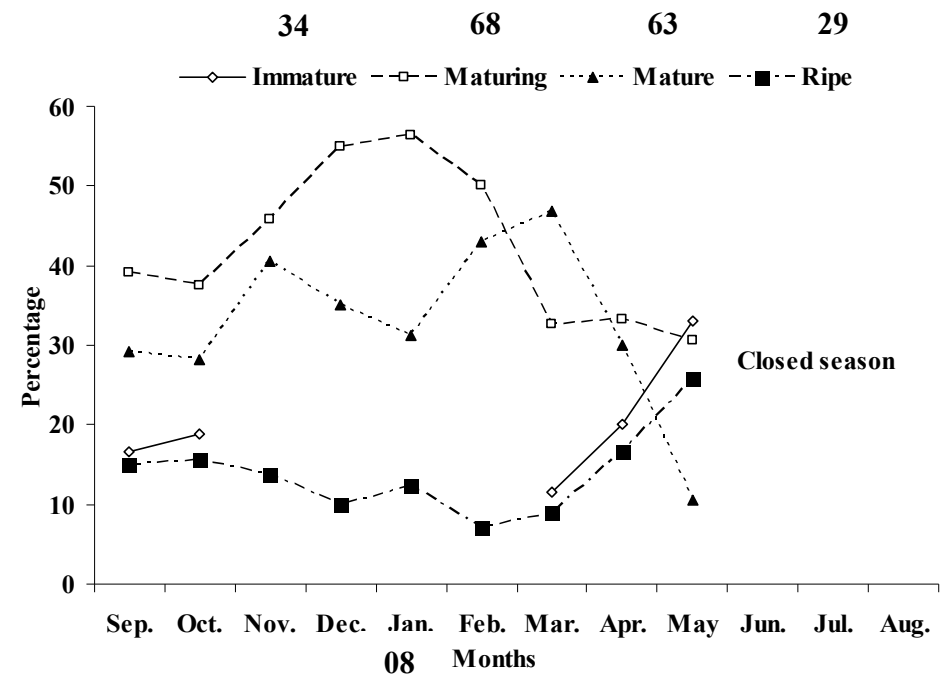

Fig. 5: Changes in the gonad condition of female Charybdis natator in respect to the different maturation stages. Numbers indicate females in each stage.

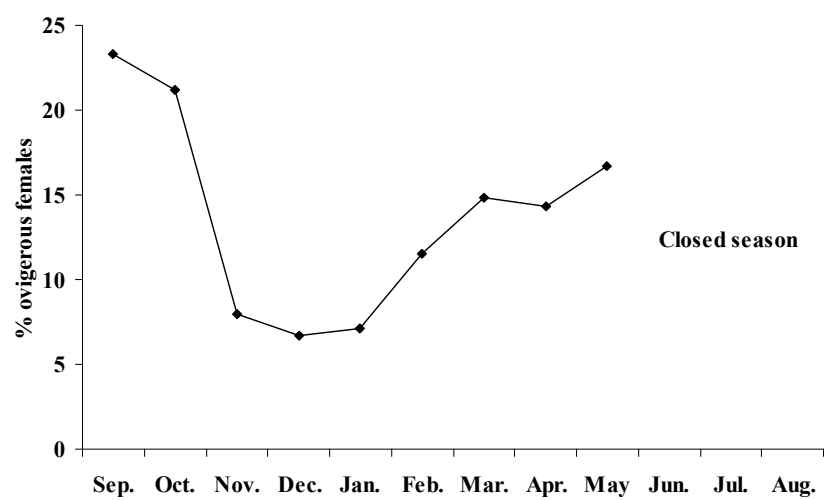

08 Months

Fig. 6: Monthly variations in the percentages of ovigerous females

Charybdis natator with developing or mature ovaries. 


\section{Size at sexual maturity:}

Of the 264 female examined, 182 were sexually mature. The relationship between carapace width $(\mathrm{CW})$ and the proportion of mature female $(P)$ by $10 \mathrm{~mm}$ size classes was calculated by fitting a logistic function to the size specific maturity data for females as follows :

$$
P=\frac{1}{\left(1+e^{(3.1825-0.0435 \mathrm{CW})}\right)} \quad\left(\mathrm{r}^{2}=0.8, P<0.05\right)
$$

From this, the estimated size for sexually mature females was $73.2 \mathrm{~mm} \mathrm{CW}$ (Fig.7).

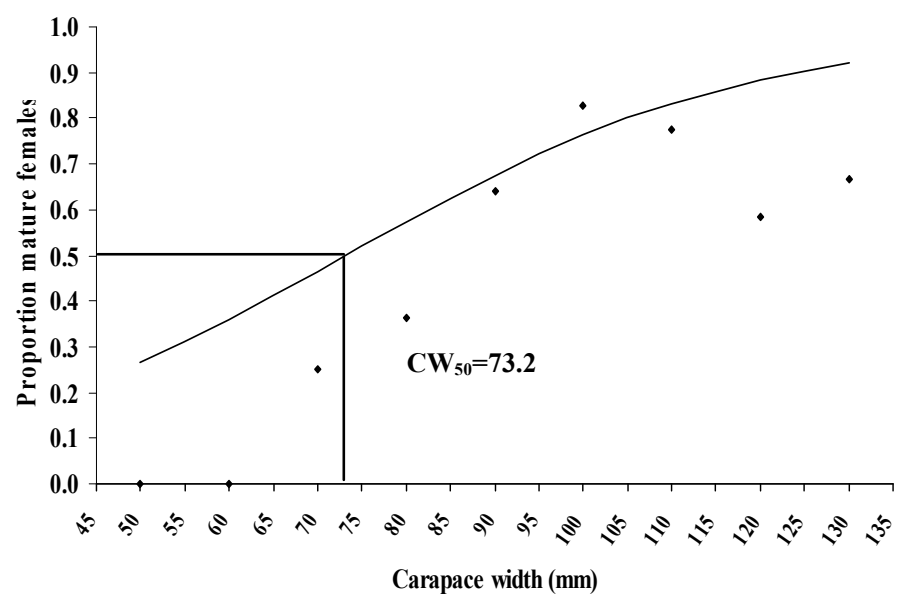

Fig. 7: Logistic function fitting proportion of mature female C. natator to carapace width. The value of $\mathrm{CW}_{50}$ which corresponds to a proportion of 0.5 is indicated.

\section{Fecundity:}

The estimated number of eggs in the egg masses of females ranging in size from $83-118.4 \mathrm{~mm} \mathrm{CW}$ was highly variable. Estimates ranged from 45230 eggs for $83 \mathrm{~mm}$ carapace width female to 335529 eggs for a female with a carapace width of $118.4 \mathrm{~mm}$. The relationship between fecundity and carapace width was: $\log$ numbers of eggs $=5.3962 \log \mathrm{CW}-12.815\left(\mathrm{r}^{2}=0.89, P<0.05\right.$, $\mathrm{N}=52$ ) (Fig.8). 


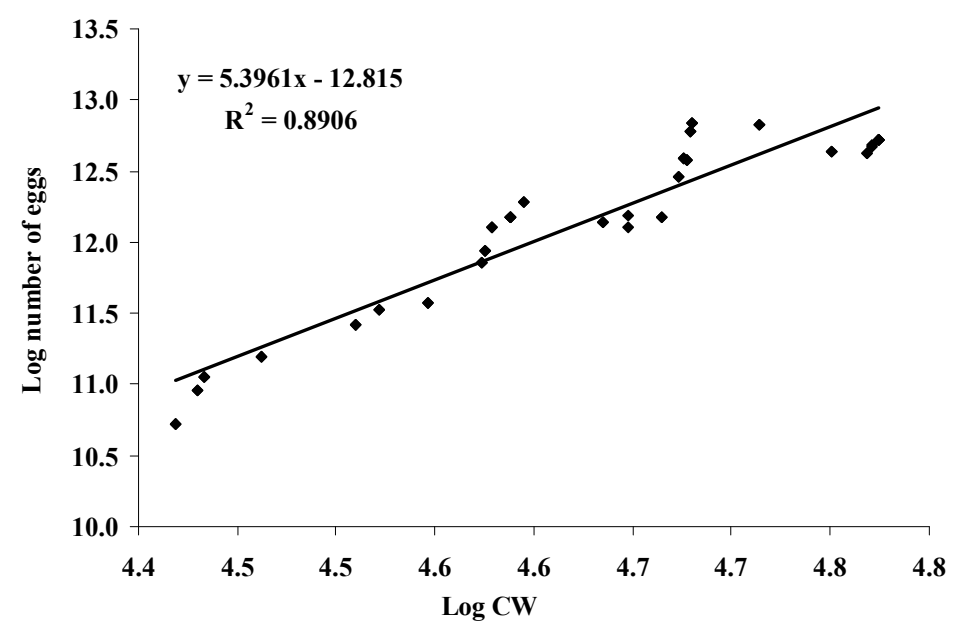

Fig. 8: Relationship between log carapace width and log batch fecundity of female Charybdis natator.

\section{DISCUSSION}

A wide range of size of the crab Charybdis. natator in the trawl fishery of the Gulf of Suez, varying between 47 and $148.5 \mathrm{~mm} \mathrm{CW}$, was recorded during the present study. This size range is slightly larger than that reported for C. natator in Moreton Bay, Australia (Sumpton, 1990b). The population supporting the Gulf of Suez fishery is exclusively constituted by large individuals and no juveniles were discernible. It is not certain as to whether the younger population of this species is not at all represented in the trawling grounds or they escape capture by the trawl nets while coexisting along with the adults. Padayatti (1990) reported absence of $C$. feriatus juveniles from the trawl fishery at Cochin and excluded the possibility of their existence in the same fishing grounds due to the presence of juveniles of other species in the catches. On the other hand, C. natator juveniles may not have a benthic life as in the case of most of the brachyuran crabs. This phenomenon has been recorded for the deep-water crab C. smithii in the Arabian Sea and Bay of Bengal (Balasubramanian \& Suseelan, 2001). A survey of the crab landings by local gears which operate in the Suez Gulf might throw light on the availability of the juvenile population of this species.

Males $C$. natator reach a larger size than females as evidenced by the largest size class, $145-155 \mathrm{~mm} \mathrm{CW}$, consisting almost entirely of males. This result is in agreement with the general pattern of brachyuran crabs. Size difference between sexes has been observed in some Charybdis species 
(Sumpton; 1990b; Padayatti, 1990; Balasubramanian \& Suseelan, 2001) as well as other brachyuran crabs (Zaghloul, 2003, Bas, et.al., 2005, Hirose \& Negreiros- Fransozo, 2008, Hartnoll, 2009). Kuhlmann and Walker (1999) stated that size structure is often variable within a species and may be subjected to environmental influences. Resource availability has also been reported to affect the abundance and size structure of organisms as it influences growth, reproduction and survival (White, 1978). Hartnoll (1982) explained that in crabs generally, males reaching a larger size since females expend greater resources on reproduction, at the expense of growth.

The sex ratio of C. natator in the Gulf of Suez was biased toward females almost throughout the year, but males predominated between September and November when breeding was found to be commencing. A similar pattern has been reported for females C. bimaculata in Tokyo Bay (Doi et.al., 2008) which was attributed to reproduction-associated migration during the reproductive season. Silas (1969) noted exclusive mono-sexed catches of $C$. smithii in Cochin and indicated the existence of sexual segregation at least during some seasons. Sex ratio deviations in crab populations usually involve sexual differences in longevity (survival rate), migration, growth rate, and even sex reversal (Wenner, 1972).

The pattern of spawning of females indicates that $C$. natator from the Gulf of Suez spawn year round. There is a prolonged breeding season commencing from March and terminating in September. The occurrence of developing and mature ovaries in most ovigerous females suggests sequential broodings occur. The same trend has been observed for Portunus pelagicus inhabiting the same region (Zaghloul, 2003) and for other species of Charybdis in other parts of the world, C. feriatus in southwestern Indian waters (Pillay and Nair, 1973), and C. bimaculata in Tokyo Bay (Doi et al., 2008). However, C. natator in the subtropical waters in Moreton Bay, Queensland had two major spawning peaks and a low percentage of females with undeveloped gonads that indicated that this species did not spawn year round (Sumpton, 1990b). In Ubatuba Bay, Brazil, ovigerous C. helleri females were present throughout most of the year with a peak of spawning activity during winter. Pillay and Nair (1973) stated that breeding in tropical crustaceans extends for several months of the year, with pronounced activity during certain months. An extended breeding season may show that individuals of a species breed asynchronously, i.e., some are in the earlier stages of maturation while others are already spent (Giese, 1959).

Females attained sexual maturity at $73.2 \mathrm{~mm} \mathrm{CW}$. Balasubramanian and Suseelan (1998) recorded size at $50 \%$ maturity for females C. smithii at 48.7 whereas those of C. bimaculata matured at $14.6 \mathrm{~mm}$ (Doi et al., 2008). Among the environmental factors influencing size at maturity, water temperature (Somerton, 1981), photoperiod condition (Hines, 1989) combined with food resources for larval development (Mantelatto, 2000) are noteworthy. Body 
weight showed sexual dimorphism, increasing relatively faster in males, and this was probably associated with the enlargement of the male chelipeds as reported for other Charybdis species, C. affinis (Chu, 1999) and C. bimaculata (Doi et al., 2008).

The estimated batch fecundity for $C$. natator in the study area was 45230- 335,529 eggs per batch for a range of carapace width of $83-118.4 \mathrm{~mm}$ CW. This estimate was much smaller than that recorded for the same species in Moreton Bay (181,230- 976,248 (100-117 mm CW) (Sumpton, 1990b) but within the range reported for other $C$. feriata $(52000-310,000)(67-112.1 \mathrm{~mm}$ CW; Padayatti, 1990). The present results indicated a good linear relationship between body size and batch size. The comparatively lower batch fecundity of C. natator than other commercial portunids in Moreton bay was not related to the limited fishery of this species since interspecific competition, habitat and environmental parameters influenced the crabs' distribution and abundance (Sumpton, 1990b). Hence, the small population of $C$. natator supporting the trawl fishery in the Gulf of Suez is probably due to interspecific competition. Sumpton (1990a) reported that the presence of $C$. natator in a trap will reduce the subsequent existence of the more commercially important species Portunus pelagicus, due to agonistic interaction.

Closed seasons are often imposed during the breeding period of the targeted species in the belief that this will increase reproductive success. Closure of fishing during the breeding period is effective only for species that is prone to disturbance or aggregates to breed or when used as a means of reducing annual fishing mortality (Arendse et.al, 2007). Subsequently, the closed season that currently runs in the Gulf of Suez region is not necessarily effective in the case of $C$. natator population since females breed all year round, however, its application would generally improve the reproductive output of this species. This edible crab is regarded as a new resource to the gulf area (Sallam \& GabAlla, 2009). Unless implications for conservation is considered, possible fishing pressure could be anticipated on this population considering the disappearance of large individuals by unregulated fishing. Further work will be necessary to the better understanding of the life history of this species which will be vital when passing regulations for the proper exploitation of this resource.

\section{REFERENCES}

Abdel-Razek, F. A. (1988). Some biological studies on the Egyptian crab Portunus pelagicus (Linnaeus, 1766). Acta Adriat., 29 (1/2): 133-143.

Al-Kholy, A. A. and El-Hawary, M.M. (1970). The biology of Lupa pelagica (Linnaeus). Biol. Inst. Ocean. Fish., 1:397-423.

Arendse, C.; Govender, J. A. and Branch, G. M. (2007). Are closed fishing seasons an effective means of increasing reproductive output? A perrecruit simulation using the limpet Cymbula granatina as a case history. Fish. Res., 85: 93-100. 
Balasubramanian, C. P. and Suseelan, C. (2001). Distribution and population structure of deep-water crab Charybdis smithii (Decapoda: Portunidae) in the Arabian Sea and Bay of Bengal. Bull. Mar. Sci., 68(3): 435-449.

Bas, C.; Luppi, T. and Spivak, E (2005). Population structure of the South American Estuarine crab, Chasmagnathus granulatus (Brachyura: Varunidae) near the southern limit of its geographical distribution: comparison with northern populations. Hydrobiology, 537(1-3):217-228.

Batoy, C.B.; Sarmago, J.F. and Pilapil, B.C. (1987). Breeding season, sexual maturity and fecundity of the blue crab Portunus pelagicus (L.) in selected coastal waters in Leyte and Vicinity, Philippines. Ann. Trop. Res., 2: 157-177.

Batoy, C.B.; Pilapil, B.C. and Sarmago, J.F. (1988). Size composition, distribution, length-weight relationship and natural food of the blue crab Portunus pelagicus (L.) in selected coastal waters in Leyte and Vicinity, Philippines. Ann. Trop. Res., 10(3/4): 127-142.

Bawab, F.M. and El-Sherif, S.S. (1988). Stages of the reproductive cycle of the female crab Portunus pelagicus (L., 1758) based on the anatomical changes of the spermatheca. Crustaceana, 54:139-148.

Chu, K.H. (1999). Morphometric analysis and reproductive biology of the crab Charybdis affinis (Decapoda, Brachyura, Portunidae) from the Zhujiang Estuary, China. Crustaceana, 72: 647-657.

Dai, A. Y.; Yang, S. L.; Song Y. Z. and Chen, G. X. (1986). Crabs of China Seas. China Ocean Press, Beijing, 568 pp., pls. 1-74.

Dai, A. Y. and Yang, S. L. (1991). Crabs of China Seas. China Ocean Press, Beijing, 608 pp., pls. 1-74.

Doi, W.; Yokota, M.; Stüssmann, C.A. and Watanabe, S. (2008). Growth and reproduction of the portunid crab Charybdis bimaculata (Decapoda: Brachyura) in Tokyo Bay. J. Crust. Biol., 28 (4): 641-651.

Giese, A.C. (1959). Comparative physiology: annual reproductive cycles of marine invertebrates. A. Rev. Physiol., 21: 547-576.

Hartnoll, R. G. H. (1982). Growth, pp. 119-116. In, D. E. Bliss and L. G. Abele (eds.). The Biology of Crustacea. Vol. 2. Embryology, Morphology and Genetics. Academic Press, New York.

Hartnoll, R. G. H. (2009). Population structure of the land crab Johngarthia langostoma on Ascension Island. J. Crust. Biol., 29(1): 57-61.

Heasman, M.P.; Fielder, D.R. and Shepherd, R. K. (1985). Mating and spawning mud crab Scylla serrata (Forskåll) (Decapoda: Portunidae). Aust. J. Mar. Freshwat Res., 36: 773-783.

Hill, B. J. (1980). Effect of temperature on feeding and activity of Scylla serrata. Mar. Biol., 59:189-192. 
Hill, B. J; Williams, M. J. and Dutton, P. (1982). Distribution of juvenile, subadult and adult Scylla serrata (Crustacea: Portunidae) on tidal flats in Australia. Mar. Biol., 69:117-120.

Hines, A. H. (1989). Geographic variation in size at sexual maturity in brachyuran crabs. Bull. Mar. Sci,. 45 (2): 356-368.

Hirose, G L. and Negreros-Fransozo, M. L. (2008). Population biology of Uca maracoani Latreille 1802-1803 (Crustacea, Brachyura, Ocypodidae) on the south-eastern coast of Brazil. Pan-Amer. J. Aquat. Sci,. 3(3): 373-383.

Hyland, S. J.; Hill, B. J. and Lee, C. P. (1984). Movement within and between habitats by the portunid crab Scylla serrata. Mar. Biol., 14: 104-110.

Islam, Md. S., Shokita, S. and Higa, T. (2000). Larval development of the swimming crab Charybdis natator (Crustacea: Brachyura: Portunidae) reared in the laboratory. Sp. Div., 5: 329-349.

Kangas, M. I. (2000). Synopsis of the biology and exploitation of the blue crab Portunus pelagicus Linnaeus in western Australia. Fish. Res. Rep., 121: 1-22.

Kuhlmann, M. L. and Walker, R. E. (1999). Geographic variation in size structure and size at maturity in the crab Pilumnus sayi (Crustacea: Decapoda: Xanthidae) in the northern Gulf of Mexico. Bull. Mar. Sci., 64 (3): 535-541.

Lui, K. K.Y.; Ng, J.S.S and Leung, K. M.Y. (2007). Spatio-temporal variations in the diversity and abundance of commercially important Decapoda and Stomatopoda in subtropical Hong Kong waters. Est., Coast. Shelf. Sci., 72 (4), p: 635-647.

Mantelatto, F.L.M. (2000). Allocation of the portunid crab Callinectes ornatus (Decapoda: Brachyura) in the Ubatuba Bay. Northern coast of São Paulo State, Brazil. Crust. Issues 12:431-443.

Menon, M.K. (1952). A note on the bionomics and fishery of the swimming crab Neptunus sanguinolentus (Herbst) on the Malabar coast. J. Zool. Soc. India, 4: 177-184.

Padayatti, P.S. (1990). Notes on population characteristics and reproductive biology of the portunid crab Charybdis feriatus (Linnaeus) at Cochin. Indian. J. Fish., 37 (2): 155-158.

Pillay, K. K. and Nair, N. B. (1973). Observations on the biochemical changes in gonads and other organs of Uca annulipes, Portunus pelagicus and Metapenaeus affinis (Decapoda: Crustacea) during the reproductive cycle. Mar. Biol., 18, 167-198.

Sallam, W. S. and Gab-Alla, A. A. (2009). Edibility assessment of the portunid crab Charybdis natator (Brachyura: Portunidae) from the Gulf of Suez, Red Sea, Egypt. Egypt. J. Aquat. Biol. Fish.13, (1): 43-54.

Silas, E.G. (1969). Exploratory fishing by RV Varuns. Bull. Cent. Mar. Fish. Res. Inst. Cochin, India, 12: 1-86. 
Somerton, D.A. (1981). Regional variation in the size of maturity of two tanner crabs (Chionoecetes bairdi and Chionoecetes opilio) in Bering Sea, and its use in defining management sub-areas. Can. J. Fish. Aquat. Sci., 37: 163-174.

Stephenson, W. Hudson, J. J. and Campbell, B. (1958). The Australian Portunidae (Crustacea: Portunidae). II. The genus Charybdis. Aust. J. Mar. Freshwat. Res., 8: 491-507.

Sumpton, W.D. (1990a). Morphometric growth and fisheries biology of the crab Charybdis natator, (Herbst) in Moreton Bay, Australia (Decapoda, Brachyura). Crustaceana 59 (2). 113-120.

Sumpton, W.D. (1990b). Biology of the rock crab Charybdis natator, (Herbst) (Decapoda, Brachyura). Bull. Mar. Sci., 46 (2). 425-431.

Wang, H.; Wu, H.; Wang, Z.; Wang, X. and Wang, Sh. (2001). Fisheries biology of Portunus pelagicus (L) initiating investigation. Mar. Sci. HaiyangKexue, 25 (1): 36-39.

Wenner, A. M. (1972). Sex ratio as a function of size in marine Crustacea. Amer. Natur., 106: 321-350.

White, T.C. R. (1978). The importance of relative shortage of food in animal ecology. Oecologia, 33: 71-86.

Zaghloul, S.S. (2003). Studies on the reproductive biology and rearing of portunid crabs in Suez Bay. Ph.D. thesis, Suez Canal University, Egypt. pp121.

Zar, J. H. (1984). Biostatistical analysis. Prentice Hall International, 718 pages. 